\title{
Application of Laser Shock Processing
}

Jan Brajer ${ }^{1,2}$, Jan Mádl $^{1}$, Roman Švábek ${ }^{2}$, Zdeněk Pitrmuc ${ }^{1}$,Danijela Rostohar ${ }^{2}$, Pavel Zeman ${ }^{1}$, José Luis Ocaña ${ }^{3}$

${ }^{1}$ Department of Machining, Process Planning and Metrology, Czech Technical University in Prague, Technická 4, 16607 Prague 6 Dejvice, Czech Republic E-mail: J.brajer@fs.cvut.cz

${ }^{2}$ HiLASE Centre, Institute of Physics ASCR, Za Radnicí 828, 25241 Dolní Břežany, Czech Republic E-mail: brajer@fzu.cz

${ }^{3}$ Centro Láser UPM (Universidad Politécnica de Madrid) Ctra. de Valencia, km. 7,3. 28031 Madrid. Spain. E-mail: jlocana@etsii.upm.es

Laser Shock Processing (LSP), or strengthening the material surface by laser shock wave is very modern and progressive technique, which allows a significant increase in fatigue life of cyclically loaded parts. The compressive residual stresses are generated in the surface layer of material processed by laser beam, which can significantly improve the fatigue properties of the material and reduce the initiation and propagation of the surface cracks. This technique finds practical use of the most demanding applications like in the aerospace industry. For this reason, we are mapping the selected surface properties after the laser treatment for the better understaning of technology possibilities. After that another suitable applications can be found. It is also important to determine appropriate parameters for different types of material and requirements affecting the result.

Keywords: Laser shock processing, surface integrity, residual stress

\section{Acknowledgements}

This work was supported by the Grant Agency of the Czech Technical University in Prague, grant No. SGS13/188/OHK2/3T/12. And this work benefitted from the support of the Czech Republic's Ministry of Education, Youth and Sports to the HiLASE (CZ.1.05/2.1.00/01.0027) and DPSSLasers (CZ.1.07/2.3.00/20.0143) projects cofinanced from the European Regional Development Fund.

\section{References}

[1] OCANA, J. L., MORALES, M., MOLPECERES, C. AND TORRES, J. (2004). Numerical simulation of surface deformation and residual stresses fields in laser shock processing experiments, Applied Surface Science, , pp. 242248.

[2] CHASWAL, V. (2012). A study of Laser Shock Peening on Fatigue behavior of IN718Plus Superalloy. University of Cincinnati

[3] PEYRE, P., FABBRO, R., MERRIEN, P., Lieurade, H. P., (1996) Laser shock processing of aluminum alloys, application to high cycle fatigue behaviour. Materials Science and Engineering; A210:102-13.

[4] JOHNSON, J. N., RHODE, R. W., J. A., (1971) Study of Laser Shock Peening on Fatigue behavior of IN718Plus Superalloy, Applied Physics, 42, pp. 171-182

[5] MAAWAD, E., BROKMEIER, H., WAGNER, L., SANO, Y., GENZEL, C., (2011) Surface Coating Technology 205, pp. 3644-3650

[6] SEE, D. W., DUlANEY, J. L., ClAUER, A. H., TENAGLIA, R. D., (2002) Surf. Engng. 18, pp. 32-36

[7] ZHOU, Z., BHAMARE, S., RAMAKRISHNAN, G., MANNAVA, S. R., LANGER, K., WEN, Y., QIAN, D., VASUDEVAN, V. K., (2012) Surface and Coatings Technology 206 (22), pp. 4619-4627

[8] DANE, C. B., HACKEL, L. A., HALPIN, J. M., DALY, J., HARRISSON, J., HARRIS, F., (2000) Proceedings - Society of Photo-Optical Instrumentation Engineers, ISSN 1018-4732 Bellingham, WA, USA, 3887, pp. 211221

[9] CHASWAL, V., MANNAVA, S. R., QAIN, D., LANGER, K.,VASUDEVAN, V. K., (2010) 2nd International Conference on LSP, San Francisco CA April pp. 17-21,

[10] NAKANO H, TSUYAMA M, MIYAUTI S, SHIBAYANAGI T, TSUKAMOTO M, ABE N, J. (2010) Laser Micro Nanoeng. 5, 2, pp. 175-178

[11] CLAUER, A. H., LAHRMAN, D. F., (2001) Key Eng. Mat. 197, pp. 121-142

[12] WEERTMAN, J., (1986) Mechanics of Materials 5 (1), pp. 13-28,

[13] KOCKS, U. F., MECKING, H., (2003) Progress Material Science 48 (3), pp. 171-273, 
[14] PEYRE, P., FABBRO, R., MERRIEN, P., LIEURADE, H.P., (1996) Materials Science and Engineering A210 pp. 102-113

[15] TRDAN, U., OCANA, J. L., GRUM, J., (2011) Mechanical Engineering., 57/5, 385

[16] SVABEK, R., ROSTOHAR, D., LUCIANETTI, A., ENDO, A., MOCEK, T., (2014) Diode-pumped kW - class lasers for efficient peening, HiLASE Project,

[17] WILCOX, R., BROWNING, D., PENKO, F., (1998) Third annual international conference on solid state lasers for application to inertial confinement fusion, Monterey, California, June 7-12th.

[18] HRABOVSKY, T., NESLUSAN, M., MICIETA, B., CILliKOVA, M., MiCIETOVA, A., (2014) 1 Barkhausen Noise Emission of Surfaces Produced by Hard Milling Process. In: Manufacturing Technology, Vol.14, No. 1, pp. 17-23. ISSN 1213-2489. Czech Republic.

[19] MADL, J., RAZEK, V., KOUTNY, V., KAFKA, J., (2013) 2 Surface Integrity in Notches Machining. In: Manufacturing Technology, Vol.14, No. 1, pp.17-23. ISSN 1213-2489. Czech Republic.

[20] STANČEKOVÁ, D., SEMCER, J., DERBAS, M., KURNAVA, T., (2013) Methods of Measuring of Residual Stresses and Evaluation of Residual State of Functional Surfaces by X-Ray Diffractometric Methods. In: Manufacturing Technology, Vol.13, No. 4, pp. 547-552. ISSN 1213-2489. Czech Republic.

[21] NESLUSAN, M., ROSIPAL, M., KOLARIK, K., OCHODEK, V., (2012) Application of Barkhausen Noise for Analysis of Surface Integrity after Hard Turning. In: Manufacturing Technology, Vol.12, No. 1, pp. 60-65. ISSN 1213-2489. Czech Republic.

[22] MADL, J., (2012) Surface Properties in Precise and Hard Machining. In: Manufacturing Technology, Vol.12, No. 1, pp. 158-166. ISSN 1213-2489. Czech Republic.

[23] CUBAN J., CALONIUS O., PIETOLA M., JERSAK J. (2011) 11 Fatigue life and surface integrity measurements of EN S355J2 steel used in hydraulic components. In: Manufacturing Technology, Vol.12, No. 1, pp. 5-11. ISSN 1213-2489. Czech Republic.

[24] SVABEK, R., ROSTOHAR, D., LUCIANETTI, A., MOCEK, T., (2014), HiLASE multi-slab laser system: a tool for efficient peening. In: Proceedings of the Manufacturing Science and Engineering Conference. June 9-13, 2014, Detroit, Michigan, USA ASME2014

[25] MADL, J., (1988) Experimentální metody v teorii obrábění, ČVUT, Praha Richard D. Tenaglia \& David F. Lahrman Box 1. The laser-peening proces Surface treatment: Shock tactics Nature Photonics 3, 267 - 270 (2009) ISSN: 1749-4885 